\title{
Uji Patogenisitas Jamur Metarhizium rileyi (Farlow) Isolat Tomohon Terhadap Larva Ulat Grayak Spodoptera frugiperda (Lepidoptera: Noctuidae)
}

\author{
(Pathogenicity Test of the Fungus Metarhizium rileyi (Farlow) Against Larvae \\ Spodoptera frugiperda (Lepidoptera: Noctuidae))
}

Indry A. Mullo*, Parluhutan Siahaan, Lalu Wahyudi Jln. Kampus UNSRAT FMIPA, Manado 95115

Program Studi Biologi, Jurusan Biologi FMIPA UNSRAT Manado, 95115

*Email korespondensi: indrymullo24@gmail.com

(Article History: Received Sep 15, 2021; Revised Jan 20, 2022; Accepted Feb 2, 2022)

\begin{abstract}
Abstrak
Ulat grayak frugiperda (Spodoptera frugiperda) merupakan salah satu hama serangga dari Ordo Lepidoptera yang menyerang perkebunan jagung di Kota Tomohon. Salah satu upaya untuk mengendalikan hama yaitu dengan pemanfaatan entomopatogen. Penelitian ini bertujuan untuk menganalisis patogenisitas jamur entomopatogen isolat Tomohon terhadap Larva S. frugiperda. Penelitian ini dilakukan secara in-vitro dengan menggunakan metode eksperimental. Data dianalisis menggunakan analisis probit dan uji Anava pada taraf 95\% dan uji beda nyata terkecil pada taraf kepercayaan 5\%. Hasil penelitian menunjukkan bahwa jamur entomopatogen yang menyerang larva $S$. frugiperda merupakan spesies Metarhizium rileyi. Persentase mortalitas perlakuan yang paling cepat mematikan larva hingga mencapai rata-rata mortalitas $100 \%$ yaitu kerapatan spora $10^{9}$ konidium $/ \mathrm{ml}$ hanya membutuhkan waktu tujuh hari setelah perlakuan (HSP). Nilai $L T_{50}$ yaitu 4 hari, dan nilai $L C_{50}$ yaitu konsentrasi $10^{5,4}$ konidium/ml. Untuk hasil analisis rata-rata persentase mortalitas $S$. frugiperda pada empat HSP dengan menggunakan uji anava menunjukkan adanya perbedaan pada mortalitas tiap perlakuan.
\end{abstract}

Kata Kunci: Metarhizium rileyi; entomopatogen; Spodoptera frugiperda

\begin{abstract}
The armyworm frugiperda (Spodoptera frugiperda) is one of the insect pests of the Order Lepidoptera that attacks corn plantations in Tomohon City. One of the efforts to control pests is the use of entomopathogens. This study aims to identify and analyze the pathogenicity of the entomopathogenic fungus Tomohon isolate against larvae $S$. frugiperda. This research was conducted in-vitro using experimental methods. Data were analyzed using probit analysis and Anova test at $95 \%$ level and the smallest significant difference test at 5\% confidence level. The results showed that the entomopathogenic fungus that attacked the larvae of S. frugiperda was a species of Metarhizium rileyi. The mortality percentage of the treatment that killed the larvae the fastest until it reached an average mortality of $100 \%$, namely spore density of $10^{9}$ only took seven days after treatment (DAT). The $L T_{50}$ value is 4 days, and the $L C_{50}$ value is a concentration of 5.4. For the results of the analysis of the average mortality percentage of $S$. frugiperda carried out on four DAT using the ANOVA test, there were differences in the mortality of each treatment.
\end{abstract}

Keywords: Metarhizium rileyi; entomopathogen; Spodoptera frugiperda

\section{PENDAHULUAN}

Ulat grayak (Spodoptera frugiperda) frugiperda merupakan serangga dari Ordo Lepidoptera yang menyerang lebih dari 80 spesies tanaman antara lain tanaman jagung, 
tebu, dan kapas (Nonci et al. 2019). Hama ini dapat menjadi ancaman terhadap produksi hasil pertanian di Indonesia, sehingga perlu dilakukannya studi mengenai pengendalian hama ini (Bagariang et al. 2020). Pada umumnya pengendalian hama yang dilakukan petani adalah menggunakan insektisida sintetis yang dinilai paling praktis. Namun jika penggunaanya secara berlebihan maka akan berdampak negatif pada lingkungan dan dapat menimbulkan resistensi pada hama sasaran (Susniahti et al. 2017). Oleh karena itu, diperlukan alternatif pengendalian hama yang lebih efektif dan aman bagi lingkungan. Salah satunya yaitu dengan memanfaatkan mikroorganisme yang bersifat entomopatogen seperti jamur.

Jamur $M$. rileyi dahulu merupakan Nomuraea rileyi yang telah dipelajari sebagai alternatif dalam pengelolaan hama Lepidoptera karena risiko yang ditimbulkan oleh jamur ini terhadap musuh alami atau penyerbuknya tidak ada, sehingga penggunaannya lebih aman, jika dibandingkan dengan pestisida kimiawi (Barros et al. 2020). Patogenisitas dari suatu organisme agens hayati juga dapat dilihat dari nilai Lethal time $\left(\mathrm{LT}_{50}\right)$ dan Lethal concentration $\left(\mathrm{LC}_{50}\right)$, dimana $\mathrm{LT}_{50}$ adalah waktu yang dibutuhkan suatu organisme agens hayati untuk mematikan $50 \%$ serangga hama yang diuji dan $\mathrm{LC}_{50}$ merupakan konsentrasi yang dapat menyebabkan kematian $50 \%$ dari serangga uji (Hasyim et al. 2019).

Di Kota Tomohon terdapat perkebunan jagung yang sudah lama ditanami jagung, dan salah satu hama yang paling sering menyerang adalah S. frugiperda. Selama ini petani mengendalikan hama dengan menggunakan pestisida, namun kenyataan dilapangan pada lokasi ini secara alami terdapat musuh alami $M$. rileyi, akan tetapi sampai saat ini penelitian tentang patogenisitas $M$. rileyi terhadap ulat grayak yang banyak menyerang tanaman jagung belum pernah dilakukan terlebih khusus untuk isolat Tomohon. Penelitian bertujuan untuk menganalisis patogenisitas jamur $M$. rileyi isolat Tomohon terhadap Larva S. frugiperda.

\section{METODE PENELITIAN Waktu dan Tempat Penelitian}

Penelitian ini dilaksanakan pada bulan Desember 2020 sampai dengan April 2021. Eksplorasi serangga dilakukan di Perkebunan jagung puncak Wawo di Kelurahan Walian, Kecamatan Tomohon Selatan, Kota Tomohon. Uji patogenisitas dilakukan di Laboratorium Agens Hayati di Balai Perlindungan dan Pengujian Mutu Tanaman Pangan dan Hortikultura (BPPMTPH) Kalasey Provinsi Sulawesi Utara.

\section{Alat dan Bahan}

Alat yang digunakan yaitu cawan petri, kawat ose, lampu bunsen, hiclave, hot plate, laminar, timbangan analitik, botol plastik, gelas plastik, aluminium foil, kantong plastik kemasan, hand sprayer, erlenmeyer, beaker glass, kulkas, mikroskop, kaca objek, pinset, mikropipet, vortex, haemocytometer, contador. Bahan yang digunakan adalah PDA, chloramphenicol, aquades steril, alkohol 70\%, beras, kapas, tissue, baby corn.

\section{Prosedur Penelitian}

Penelitian menggunakan metode eksperimental dengan Rancangan acak lengkap (RAL) dengan faktor tunggal. 
Faktor perlakuan yang diuji yaitu kerapatan spora $(\mathrm{k})$ jamur $M$. rileyi yang terdiri dari enam taraf, sebagai berikut :

$\mathrm{k} 0$ : 0 (kontrol)

$\mathrm{k} 1: 10^{5}$ konidium $/ \mathrm{ml}$

$\mathrm{k} 2: 10^{6}$ konidium $/ \mathrm{ml}$

$\mathrm{k} 3: 10^{7}$ konidium $/ \mathrm{ml}$

$\mathrm{k} 4: 10^{8}$ konidium $/ \mathrm{ml}$

$\mathrm{k} 5: 10^{9}$ konidium $/ \mathrm{ml}$

Setiap perlakuan diulang sebanyak lima kali, masing-masing ulangan terdiri dari 10 serangga yang diletakkan pada 10 wadah berbeda (1 wadah terdiri dari 1 ekor larva).

\section{Perbanyakan \\ Entomopatogen $M$. rileyi}

Jamur

Isolat jamur entomopatogen yang digunakan hasil dari eksplorasi pada tanaman jagung dengan mengumpulkan larva yang terserang jamur entomopatogen. Isolat jamur dikulturkan pada media Potato Dextrose Agar (PDA) hingga murni, dan untuk memastikan spesies jamur yang digunakan maka dilakukan identifikasi molekuler melalui PCR dengan hasil menunjukkan bahwa $100 \%$ identitas isolat termasuk dalam jamur M. rileyi (Siahaan dan Mullo 2021). Isolat jamur yang telah tumbuh murni pada media PDA selanjutnya diperbanyak pada media beras yang dibersihkan terlebih dahulu, ditiriskan dan dimasak selama kurang lebih 20 menit hingga lunak. Setelah masak, beras dibiarkan dingin terlebih dahulu kemudian dimasukkan ke dalam kantung plastik yang tahan panas sebanyak 100 gr dan distaples. Beras yang telah dibungkus kemudian disterilkan dengan menggunakan autoclave pada suhu $121^{\circ} \mathrm{C}$ selama 20 menit. Setelah disterilkan, beras diangkat dan dibiarkan hingga dingin selama 24 jam (Pertiwi et al. 2016).

\section{Pemeliharaan Larva $S$. frugiperda}

Pengambilan kelompok telur dilakukan pada permukaan bawah daun tanaman jagung yang menunjukan gejala kerusakan. Kelompok telur larva yang didapat dimasukkan ke dalam plastik klip yang selanjutnya dibawa ke laboratorium untuk diidentifikasi dan dipelihara. Sampel larva yang telah dibawa ke laboratorium kemudian diletakkan pada wadah lalu diberi makan baby corn secara rutin agar larva tetap hidup. Larva dipelihara sampai menjadi pupa dan menjadi dewasa dan menghasilkan telur baru. Telur yg dihasilkan dipelihara sampai mencapai instar 3 (Tim ISO 2015).

\section{Uji Hayati Patogenisitas Jamur Entomopatogen Terhadap Larva $S$. frugiperda}

Suspensi diambil dengan menggunakan pipet, kemudian diteteskan pada haemocytometer dan diamati dibawah mikroskop dengan perbesaran $400 \times$ dan dihitung kerapatan konidium/ml pada tiap kamar hitung. Perhitungan kerapatan spora terus dilakukan hingga didapatkan jamur dengan kerapatan spora $10^{9}$. Jamur dengan kerapatan spora $10^{9}$ konidium $/ \mathrm{ml}$ diencerkan untuk mendapatkan empat taraf perlakuan yaitu $10^{5}, 10^{6}, 10^{7}, 10^{8}$ konidium $/ \mathrm{ml}$. Pengenceran dilakukan dengan mengambil jamur yang sudah mempunyai kerapatan $10^{9}$ konidium/ml sebanyak 100 gram, kemudian ditambahkan aquades sampai $1000 \mathrm{ml}$. Untuk membuat konsentrasi $\quad 10^{8} \quad$ konidium $/ \mathrm{ml}$ dilakukan dengan diambil sebanyak 10 $\mathrm{ml}$ dari suspensi konsentrasi $10^{9}$ konidium/ml, dan ditambahkan aquades sampai $100 \mathrm{ml}$. Demikian seterusnya sampai diperoleh konsentrasi $10^{5}$ konidium $/ \mathrm{ml}$. Ke 
dalam setiap wadah dimasukkan satu ekor larva $S$. frugiperda instar ketiga yang terdapat baby corn sebagai sumber pakan. Kemudian masingmasing suspensi diaplikasikan pada larva uji sebanyak $10 \mathrm{ml}$ dengan cara disemprotkan menggunakan sprayer. Pengamatan mortalitas larva uji dilakukan setiap hari dimulai dari satu hari setelah aplikasi sampai mortalitas mencapai $100 \%$ (Tim ISO 2015).

\section{Analisis Data}

Analisis data terhadap morfologi dengan cara mendiskripsikan karakteristik morfologinya dan menghitung kerapatan spora dengan rumus:

$\mathrm{S}=\frac{\bar{X}}{\mathrm{~L} \times \mathrm{t} \times \mathrm{d}} \times 10^{3}$

Keterangan :

$\mathrm{S}=$ kerapatan konidium $/ \mathrm{ml}$

$\bar{X}=$ rerata jumlah konidium pada kotak

a,b,c,d,e

$\mathrm{L}=$ luas kotak hitung $0,04 \mathrm{~mm} 2$

$\mathrm{t}=$ kedalaman bidang hitung $0,1 \mathrm{~mm}$

$\mathrm{d}=$ faktor pengenceran

$10^{3}=$ volume suspensi yang dihitung $(1$ $\mathrm{ml}=10^{3} \mathrm{~mm}^{3}$ )

Untuk mencari Lethal Concentration 50 (LC50) dan Lethal Time 50 (LT50) akan dihitung menggunakan analisis probit dengan menggunakan program aplikasi SPSS versi 22.0 dan dianalisis dengan Uji Anava pada taraf 95\% dan bila ada perbedaaan antar perlakuan akan dilanjutkan dengan uji beda nyata terkecil pada taraf kepercayaan 5\%.

\section{HASIL DAN PEMBAHASAN Mortalitas}

Hasil didapatkan perlakuan yang paling cepat mematikan larva hingga mencapai rata-rata mortalitas $100 \%$ merupakan perlakuan dengan kerapatan konidia K5 yaitu pada tujuh HSP, dan diikuti oleh perlakuan dengan kerapatan konidia K4 dan K3 yang pada delapan HSP sudah mampu mematikan larva dengan rata-rata mortalitas mencapai 100\% (Gambar 1). Pada hari kesembilan dapat dilihat rata-rata mortalitas pada semua perlakuan telah mencapai $100 \%$, hal ini sesuai dengan penelitian yang dilakukan oleh Fronza et al. (2017) bahwa periode kontak awal $M$. rileyi dengan inang, dari perkembangan proses infektif sampai pada kematian serangga yang meliputi perkecambahan konidial, dan perkembangan serangga sampai siklus penuh pada inang memiliki waktu rata-rata enam sampai delapan hari yang bervariasi sesuai dengan strain dan spesies inang yang terlibat.

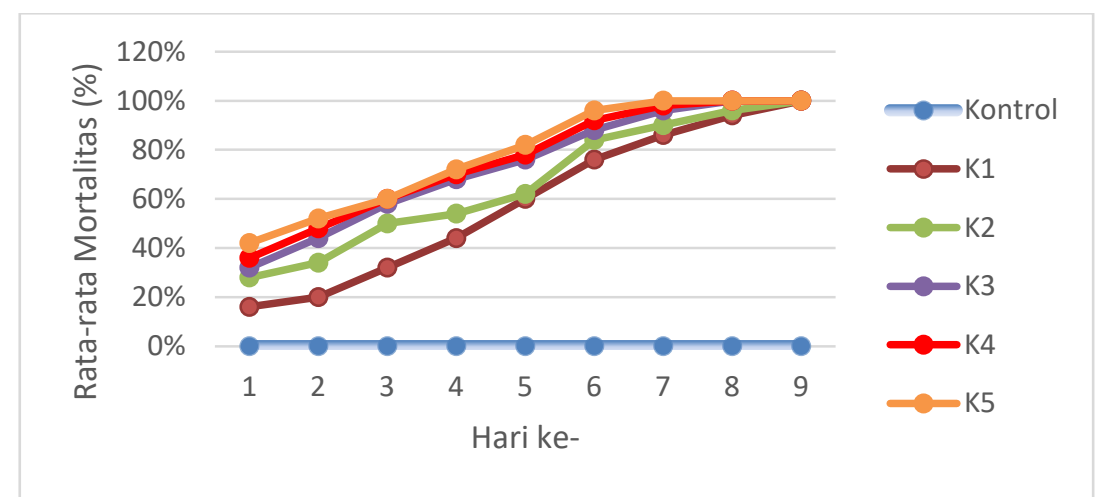

Gambar 1. Grafik persentase mortalitas ulat grayak frugiperda (S. frugiperda) setelah aplikasi beberapa isolat $M$. rileyi. 
Lethal Time $50\left(\mathbf{L T}_{50}\right)$ dan Lethal Consentration $50\left(\mathrm{LC}_{50}\right)$

Patogenisitas dari jamur M. rileyi dapat dilihat dari waktu yang dibutuhkan untuk mematikan 50\% larva S. frugiperda. Nilai $\mathrm{LT}_{50}$ menunjukkan tidak adanya perbedaan waktu yang sangat jauh karena dari masing-masing perlakuan memiliki nilai yang hampir sama yaitu berada pada kisaran waktu empat sampai lima hari setelah aplikasi (Tabel 1). Hal ini sesuai dengan penelitian yang telah dilakukan oleh Montecalvo dan Navasero (2020) yang menyatakan bahwa pada hari ke empat sampai hari ke lima kematian larva meningkat secara signifikan.

Tabel 1. Nilai $\mathrm{LT}_{50}$ dan $\mathrm{LC}_{50}$ perlakuan isolat M. rileyi pada larva S. Frugiperda

\begin{tabular}{cccc}
\hline Serangga & Konsentrasi & LT $_{50}($ Hari $)$ & $\begin{array}{c}\mathrm{LC}_{50} \\
(\text { Konidium/ml) }\end{array}$ \\
\hline & $1 \times 10^{5}$ & 4,8 & \\
S. frugiperda & $1 \times 10^{6}$ & 4,8 & 5,4 \\
& $1 \times 10^{7}$ & 4 & \\
& $1 \times 10^{8}$ & 4,2 & \\
$1 \times 10^{9}$ & 4,1 & \\
\hline
\end{tabular}

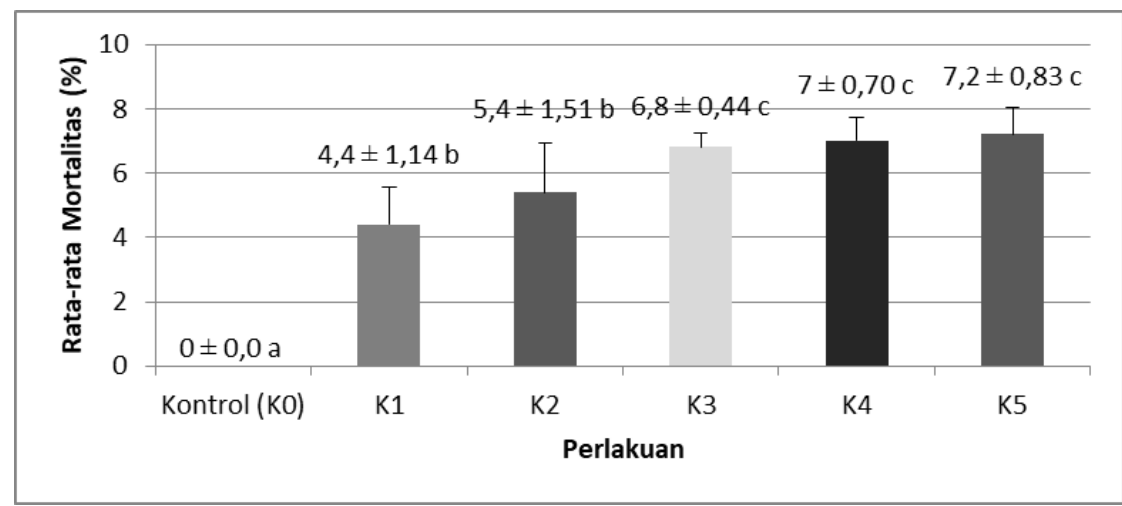

Gambar 2. Hasil analisis mortalitas $S$. frugiperda pada hari keempat \pm Standar Deviasi; Huruf kecil yang sama diatas bar menunjukkan tidak berbeda nyata berdasar uji BNT pada $\alpha 5 \%$.

Patogenisitas dari suatu agens hayati juga dapat dilihat dari tingkat konsentrasi yang dapat menyebabkan kematian $50 \%$ larva $\left(\mathrm{LC}_{50}\right) \quad S$. frugiperda. Hasil perhitungan menggunakan analisis probit bahwa konsentrasi yang dapat menyebabkan kematian $50 \%$ pada larva $S$. frugiperda yaitu pada konsentrasi $10^{5,4}$ konidiuim/ml (Tabel 1). Berbeda dengan penelitian yang dilaporkan oleh Rajan dan Muthukrishnan (2009), nilai $\mathrm{LC}_{50}$ pada larva $S$. litura instar tiga menunjukkan bahwa isolat lokal memiliki nilai $\mathrm{LC}_{50}$ paling tinggi yaitu $18,27 \times 10^{7}$ konidium/ml, dari hasil ini menunjukkan bahwa $M$. rileyi isolat Tomohon sangat efektif dalam membunuh larva $S$. frugiperda walaupun pada konsentrasi kerapatan konidia paling rendah. 


\section{Persentase Mortalitas Pada Hari Keempat}

Berdasarkan hasil analisis rata-rata persentase mortalitas $S$. frugiperda yang dilakukan pada hari keempat dengan menggunakan uji anava menunjukkan adanya perbedaan pada mortalitas tiap perlakuan. Pada Gambar 2 dapat dilihat hasil uji BNT yang menunjukkan bahwa perlakuan dengan kerapatan konidia $10^{5}$ (K1) dan $10^{6}$ (K2) tidak berbeda nyata, tetapi berbeda nyata antara kerapatan konidia $10^{7}(\mathrm{~K} 3), 10^{8}(\mathrm{~K} 4), 10^{9}(\mathrm{~K} 5)$ dengan Kontrol (K0). Kemudian kerapatan konidia $10^{7}(\mathrm{~K} 3), 10^{8}(\mathrm{~K} 4)$, dan $10^{9}$ (K5) tidak berbeda nyata, namun berbeda nyata dengan kerapatan konidia $10^{5}(\mathrm{~K} 1), 10^{6}(\mathrm{~K} 2)$ dan Kontrol (K0). Hasil analisis ini menunjukkan bahwa isolat lokal jamur $M$. rileyi ini mampu menginfeksi dan membunuh larva $S$. frugiperda bahkan dengan perlakuan konsentrasi paling rendah yaitu kerapatan konidia $10^{5}$ konidium $/ \mathrm{ml}$. Kematian larva $S$. frugiperda yang terinfeksi jamur $M$. rileyi mulai terjadi pada satu HSP. Pertumbuhan jamur $M$. rileyi pada permukaan tubuh larva menunjukkan terjadinya kolonisasi lengkap, dimana dapat dilihat pada Gambar 3 jamur $M$. rileyi menyelimuti pada bagian thorax dan abdomen, namun dapat dilihat jamur tidak menyelimuti pada bagian kepala. Hal ini sesuai dengan penelitian yang telah dilaporkan oleh Visalakshi et al. (2020) berdasarkan pengamatan stereomikroskopis mikosis telah menunjukkan kolonisasi lengkap dari prothorax, mesothorax, metathorax, dan semua segmen perut dengan pertumbuhan miselium jamur keputihan, kecuali pada bagian kapsul kepala, pelindung toraks, setae, dan selangkangan.

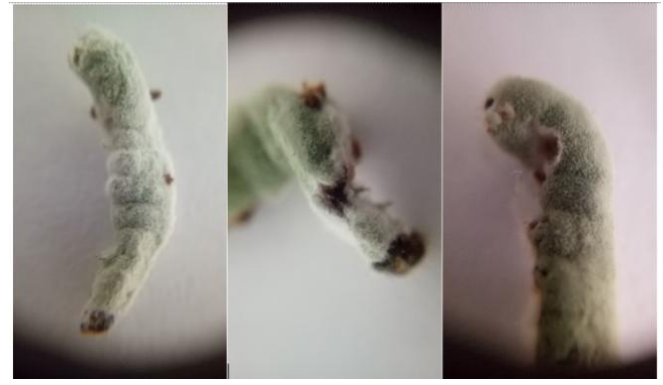

Gambar 3. Larva S. frugiperda yang dikolonisasi miselium jamur $M$. rileyi yang berbentuk seperti mumi.

Faktor-faktor yang mempengaruhi infeksi jamur adalah kelembaban. Berdasarkan penelitian yang dilakukan oleh Prayogo (2005) bahwa kelembaban yang tinggi sangat dibutuhkan oleh cendawan entomopatogen dalam pembentukan tabung kecambah (germ tube), maka dari itu agar tetap terjaga kelembaban pada wadah digunakan tissue sebagai dasar dan dibasahi dengan air. Hal ini juga sesuai dengan pengujian yang dilakukan dilapangan atau secara in vivo seperti pada penelitian yang telah dilaporkan oleh Firake dan Behere (2020) pada larva FAW di India bahwa kondisi lembab memainkan peran penting dalam epizootik jamur entomopatogen.

\section{KESIMPULAN}

Jamur entomopatogen isolat tomohon yang menyerang larva $S$. frugiperda merupakan jamur $M$. rileyi. Nilai LT $_{50}$ yaitu hanya membutuhkan waktu empat hari. Sedangkan nilai $\mathrm{LC}_{50}$ yaitu pada konsentrasi 5,4. Persentase mortalitas yang paling cepat mematikan larva hingga mencapai rata-rata mortalitas $100 \%$ yaitu perlakuan dengan kerapatan konidia K5 yaitu pada tujuh HSP. Hasil analisis rata-rata persentase mortalitas $S$. frugiperda yang dilakukan pada hari keempat HSP dengan menggunakan uji anava 
menunjukkan adanya perbedaan pada mortalitas tiap perlakuan.

\section{DAFTAR PUSTAKA}

Bagariang W, Tauruslina E, Kulsum U, Murniningtyas PLT, Suyanto $\mathrm{H}$, Surono, Cahyana NA, Mahmuda D (2020) Efektifitas Insektisida Berbahan Aktif Klorantraniliprol terhadap Larva Spodoptera frugiperda (JE Smith). Jurnal Proteksi Tanaman. 4: 29-37.

Barros SKA, Pitta RM, Lopes RB, de Almeida EG, Ferreira FTR (2020) Susceptibility of Spodoptera frugiperda and Chrysodeixis includens (Lepidoptera: Noctuidae) to infections caused by Metarhizium rileyi. Pesq. Agropec. Trop. 50: 1-7.

Firake DM, Behere GT (2020) Natural mortality of invasive fall armyworm, Spodoptera frugiperda (J. E. Smith) (Lepidoptera: Noctuidae) in maize agroecosystems of northeast India. Biological control. 148: 1-11.

Fronza E, Specht A, Heinzen H, de Barros NM (2017) Metarhizium (Nomuraea) rileyi as biological control agent. Biocontrol Science and Technology. 2: 122.

Hasyim A, Setiawati W, Lukman L, Marhaeni LS (2019) Evaluasi Konsentrasi Lethal dan Waktu Lethal Insektisida Botani Terhadap Ulat Bawang (Spodoptera exigua) di Laboratorium. J. Hort. 29(1): 6980.

Montecalvo MP, Navasero MM (2020) Metarhizium (=Nomuraea) rileyi (Farlow) Samson from Spodoptera exigua
(Hübner) Cross Infects Fall Armyworm, Spodoptera frugiperda (J.E. Smith) (Lepidoptera: Noctuidae) Larvae. Philippine Journal of Science. 150 (1): 193-199.

Nonci N, Kalqutny SH, Mirsam H, Muis A, Azrai M, Aqil M (2019) Pengenalan Fall Armyworm (Spodoptera frugiperda J.E.Smith) Hama Baru pada Tanaman Jagung di Indonesia. Balai Penelitian Tanaman Serealia, Maros.

Pertiwi SP, Hasibuan R, Wibowo L (2016) Pengaruh Jenis Formulasi Jamur Entomopatogen Beauveria bassiana Terhadap Pertumbuhan Spora Dan Kematian Kutudaun Kedelai (Aphis glycines Matsumura). J. Agrotek Tropika. 4(1): 55 - 61.

Prayogo Y (2005) Potensi, Kendala, dan Upaya Mempertahankan Keefektifan Cendawan Entomopatogen Untuk Mengendalikan Hama Tanaman. Buletin Palawija. (10): 53-65.

Rajan TS, Muthukrishnan N (2009) Pathogenicity of Nomuraea rileyi (Farlow) Samson isolates against Spodoptera litura (Fabricius). J. Biol. Control. 23(1): 17-20.

Susniahti N, Suganda T, Sudarjat, Dono D, Nadhirah A (2017) Reproduksi, Fekunditas, dan Lama Hidup Tiap Fase Perkembangan Plutella xylostella (Lepidoptera: Ypnomeutidae) pada Beberapa Jenis Tumbuhan Cruciferae. Jurnal Agrikultura. 28(1): 27-31.

Siahaan P, Mullo I (2021) Isolasi dan Identifikasi Jamur Entomopatogen Isolat Tomohon dari Larva Ulat Grayak Spodoptera frugiperda 
(Lepidoptera: Noctuidae). Journal of Biotechnology and Conservation In Wallacea. 1(1): 10-16.

Tim ISO (2015) Informasi Terdokumentasi Sistem Manajemen Mutu SNI ISO 9001:2015. Laboratorium Agens Hayati - Balai Perlindungan dan Pengujian Mutu Tanaman
Pangan dan Hortikultura Kalasey. Manado.

Visalakshi M, Varma PK, Sekhar VC, Bharathalaxmi V, Manisha BL, Upendhar S (2020) Studies on mycosis of Metarhizium (Nomuraea) rileyi on Spodoptera frugiperda infesting maize in Andhra Pradesh, India. Egyptian Journal of Biological Pest Control . 30: 1-10. 